\title{
Penerapan Latent Class Cluster Analysis (LCCA) \\ Pada Pengelompokan Kabupaten/Kota Di Provinsi Papua Barat Berdasarkan Indikator Kesejahteraan Rakyat \\ Application Of Latent Class Cluster Analysis (LCCA) to Grouping The Regency/City in The West Papua Province Based On People's Welfare Indicators Onti Sundari ${ }^{1}$, Surianto Bataradewa ${ }^{2}$, Esther Ria Matulessy ${ }^{3}$ \\ ${ }^{123}$ Jurusan Matematika, Fakultas Matematika dan Ilmu Pengetahuan Alam, UNIPA, Manokwari, 98314, Indonesia \\ Email: Onti.s95@gmail.com
}

\begin{abstract}
Latent class cluster analysis (LCCA) is one of the techniques for latent variable. Clustering of objects is done by using probability opportunities and based on statistical models. The latent variable used in this study is the welfare of the people of West Papua which is described by 15 indicator variables of public welfare in 2019. The purpose of this study is to determine the number of groups based on the best models and characteristics formed and thus obtain an early picture of the welfare conditions in the Regency/City in West Papua Province. The research was conducted based on the smallest Bayesian Information Criteria (BIC) value of 1836.9406, the best model was three clusters. The results showed that Manokwari Regency, Sorong Selatan Regency, Sorong Regency, Raja Ampat Regency, Tambrauw Regency, Manokwari Selatan Regency, and Pegunungan Arfak Regency were in first cluster; Fakfak Regency, Kaimana Regency, Maybrat Regency and Teluk Wondama Regency are in second cluster and Bintuni Regency and Sorong City are in third cluster.
\end{abstract}

Keywords: Latent Variable, LCCA, Welfare Indicator

\begin{abstract}
ABSTRAK
Latent class cluster analysis (LCCA) merupakan salah satu teknik pengelompokan untuk variabel laten. Pengelompokan objek dilakukan menggunakan peluang probabilitas dan berdasarkan model statistik. Variabel laten yang digunakan dalam penelitian ini adalah kesejahteraan rakyat Papua Barat yang digambarkan oleh 15 variabel indikator kesejahteraan rakyat Tahun 2019. Tujuan penelitian ini adalah menentukan jumlah kelompok berdasarkan model terbaik dan karakteristik yang terbentuk sehingga didapatkan gambaran awal tentang kondisi kesejahteraan di Kabupaten/Kota di Provinsi Papua Barat. Penelitian dilakukan dengan berdasarkan nilai Bayesian Information Criteria (BIC) terkecil yaitu 1836,9406 diperoleh model terbaik adalah tiga cluster. Hasil penelitian menunjukkan Kabupaten Manokwari, Kabupaten Sorong Selatan, Kabupaten Sorong, Kabupaten Raja Ampat, Kabupaten Tambrauw, Kabupaten Manokwari Selatan, dan Kabupaten Pegunungan Arfak berada dalam cluster satu; Kabupaten Fakfak, Kabupaten Kaimana, Kabupaten Maybrat dan Kabupaten Teluk Wondama berada dalam cluster dua dan Kabupaten Bintuni dan Kota Sorong berada dalam cluster tiga.
\end{abstract}

Kata Kunci: Variabel Laten, LCCA, Indikator Kesejahteraan 


\section{PENDAHULUAN}

Analisis Cluster merupakan teknik variabel ganda yang bertujuan untuk mengelompokkan objek-objek berdasarkan kemiripan karakteristik yang dimilikinya. Metode pada analisis cluster terdiri atas dua yaitu berhirarki dan tak berhirarki. Pada metode berhirarki jumlah cluster belum diketahui sedangkan metode tak berhirarki jumlah kelompok sudah diketahui terlebih dahulu. Pengukuran kemiripan objek pada kedua metode ini menggunakan ukuran jarak (Mattjik dan Sumertajaya 2011).

Analisis cluster dapat digunakan dalam beberapa skala data seperti ordinal, interval dan rasio tetapi hanya dapat diterapkan pada variabel yang terukur langsung atau observed (Nugroho, 2008). Dalam penelitian bidang sosial ekonomi dikenal variabel tak terukur langsung/unobserved atau yang dikenal dengan variabel laten. Variabel laten dapat diukur oleh beberapa variabel teramati yang disebut variabel indikator (Linda \& Stephanie, 2010). Teknik pengelompokan terus dikembangkan oleh para ahli hingga dapat digunakan untuk menangani variabel laten, salah satunya adalah Latent Class Cluster Analysis (LCCA). Menurut Vermunt dan Magidson (2002b) pengelompokan dengan LCCA menggunakan peluang probabilitas dan berdasarkan model statistik atau model based clustering. Berbeda dengan analisis cluster klasik yang bersifat subjektif, kriteria pemilihan cluster pada LCCA bersifat objektif dengan memasukkan pengujian statistik yang kuat.

Menurut Badan Pusat Statistik (2019), Provinsi Papua Barat memiliki indikator kesejahteraan yang rendah tingkatannya dibandingkan dengan provinsi lain di Indonesia dan berdasarkan Perda Provinsi Papua Barat tentang "Rencana Jangka Panjang Pemerintah Daerah" Nomor 18 Tahun 2012, salah satu prioritas pembangunan adalah memajukan kesejahteraan rakyat di bidang ekonomi dan sosial. Agar tercapainya tujuan ini, maka diperlukan gambaran awal kesejahteraan rakyat di Provinsi Papua Barat. Gambaran awal tersebut dapat diketahui melalui pengelompokan kabupaten dan kota, sehingga kebijakan prioritas yang tepat dengan tujuan pemerataan kesejahteraan rakyat disetiap daerah dapat terlaksana.

\section{METODE PENELITIAN}

Pada penelitian ini data yang digunakan merupakan data sekunder yang diperoleh dari Badan Pusat Statistika (BPS) Provinsi Papua Barat, berupa data indikator Kesejahteraan Rakyat tahun 2019 yang disajikan pada tabel 1.

Tabel 1. Variabel Penelitian

\begin{tabular}{c|l|c}
\hline Indikator & \multicolumn{1}{|c}{ Keterangan } & Skala Data \\
\hline $\mathrm{X}_{1}$ & Kepadatan Penduduk & Rasio \\
\hline $\mathrm{X}_{2}$ & Rasio Ketergantungan & Rasio \\
\hline $\mathrm{X}_{3}$ & Usia Harapan Hidup & Rasio \\
\hline $\mathrm{X}_{4}$ & Angka Morbiditas & Rasio \\
\hline $\mathrm{X}_{5}$ & $\begin{array}{l}\text { Balita Lengkap } \\
\text { Imunisasi }\end{array}$ & Rasio \\
\hline $\mathrm{X}_{6}$ & TPAK & Rasio \\
\hline $\mathrm{X}_{7}$ & TPT & Rasio \\
\hline
\end{tabular}




\begin{tabular}{c|l|l}
\hline $\mathrm{X}_{8}$ & RLS & Rasio \\
\hline $\mathrm{X}_{9}$ & HLS & Rasio \\
\hline $\mathrm{X}_{10}$ & Pengeluaran per Kapita & Rasio \\
\hline $\mathrm{X}_{11}$ & Rasio Gini & Rasio \\
\hline $\mathrm{X}_{12}$ & Akses Listrik PLN & Rasio \\
\hline $\mathrm{X}_{13}$ & Akses Air Layak Minum & Rasio \\
\hline $\mathrm{X}_{14}$ & Sanitasi & Rasio \\
\hline $\mathrm{X}_{15}$ & Bahan Bakar Memasak & Rasio \\
\hline
\end{tabular}

Langkah awal yang dilakukan dalam pengelompokan dengan metode LCCA adalah membentuk model. Secara umum model dasar LCCA dirumuskan oleh persamaan berikut (Vermunt dan Magidson, 2004):

dengan:

$$
\mathrm{f}\left(\mathrm{y}_{\mathrm{h}} \mid \theta\right)=\sum_{\mathrm{k}=1}^{\mathrm{K}} \tau_{\mathrm{k}}\left[\mathrm{g}\left(\mathrm{y}_{\mathrm{h}} \mid \theta_{\mathrm{k}}\right)\right]
$$

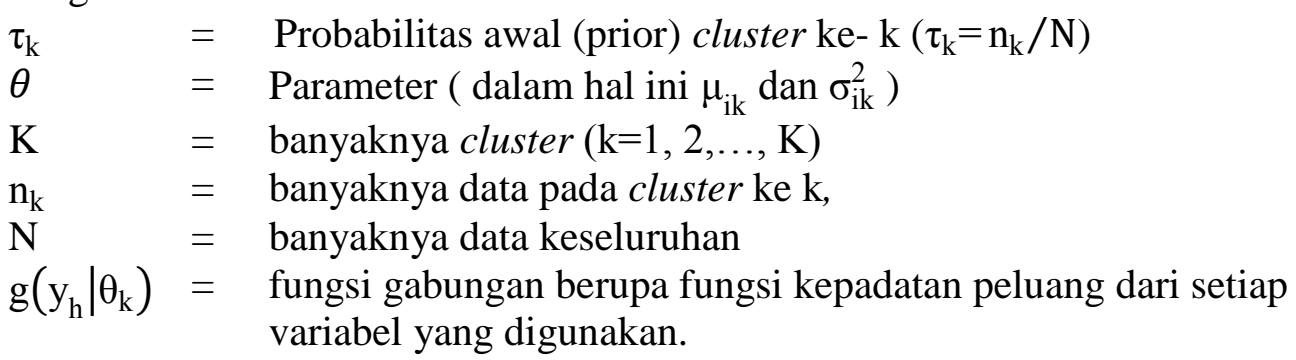

Namun sebelum pembentukan model, terlebih dahulu mengetahui jenis variabel indikator pada data yang akan digunakan sehingga distribusi variabel tersebut dapat disesuaikan. Dalam penelitian ini digunakan variabel indikator kontinu sehingga distribusi variabelnya adalah sebaran normal ganda. Fungsi kepadatan peluang (fkp) untuk variabel kontinu sebaran normal dengan parameter rataan $\mu_{\mathrm{ik}}$ dan ragam $\sigma_{\mathrm{ik}}^{2}$ dinyatakan dalam bentuk:

$$
\mathrm{g}\left(\mathrm{y}_{\mathrm{h}} \mid \mu_{\mathrm{ik}}, \sigma_{\mathrm{ik}}^{2}\right)=\frac{1}{(2 \pi)^{\mathrm{p} / 2}\left[\Pi_{i=1}^{p} \sigma_{i}^{2}\right]} \exp \left[-\frac{1}{2} \sum_{i=1}^{p}\left(\frac{\left(\mathrm{y}_{\mathrm{hi}}-\mu_{\mathrm{ik}}\right)^{2}}{\sigma_{\mathrm{ik}}^{2}}\right)\right]
$$

dengan:

$\mu_{\mathrm{ik}}=$ parameter lokasi variabel $\mathrm{ke}-\mathrm{i}$ di cluster $\mathrm{k}$

$\sigma_{\mathrm{ik}}^{2}=$ varians dari variabel ke-i di cluster $\mathrm{k}$

$\mathrm{K}=$ banyak cluster $(1,2, \ldots, \mathrm{K})$

Sehingga model LCCA dengan variabel kontinu didefinisikan dengan memasukan persamaan (2.2) ke dalam persamaan (2.1), sehingga diperoleh persamaan berikut:

$$
\mathrm{f}\left(\mathrm{y}_{\mathrm{h}} \mid \tau_{\mathrm{k}}, \mu_{\mathrm{ik}}, \sigma_{\mathrm{ik}}^{2}\right)=\sum_{\mathrm{k}=1}^{\mathrm{K}} \tau_{\mathrm{k}}\left[\frac{1}{(2 \pi)^{\mathrm{p} / 2}\left[\prod_{\mathrm{i}=1}^{\mathrm{p}} \sigma_{\mathrm{ik}}^{2}\right]} \exp \left[-\frac{1}{2} \sum_{\mathrm{i}=1}^{\mathrm{p}}\left(\frac{\left(\mathrm{y}_{\mathrm{hi}}-\mu_{\mathrm{ik}}\right)^{2}}{\sigma_{\mathrm{ik}}^{2}}\right)\right]\right]
$$

Pendugaan parameter dalam LCCA dilakukan dengan menggunakan metode maksimum likelihood. Pada kasus laten dimana terdapat data yang tidak teramati, fungsi likelihood dimaksimumkan dengan metode iteratif yaitu menggunakan Algoritma Expectation Maximization (EM) dan dilanjutkan dengan metode New Raphson (Snellman, 2008). Menurut Vermunt dan Magidson (2002b) kedua metode iterasi ini digunakan karena 
memiliki kelebihan masing-masing yaitu Algoritma EM bersifat stabil bahkan ketika nilai taksirannya jauh dari optimal, sedangkan metode New Raphson (NR) yang cepat dalam mengestimasi ketika nilainya sudah mendekati optimal. Pendugaan parameter dengan algoritma EM terdiri atas dua tahap yaitu expectation step (tahap E) dan maximization step (tahap $\mathrm{M}$ )

i. Tahap $\mathbf{E}$ bertujuan untuk mengisi atau mengganti data yang tidak teramati berupa keanggotaan dari setiap cluster. Perhitungan probabilitas posterior untuk setiap kelompok dinotasikan oleh persamaan berikut (Chadijah, 2016):

$$
\begin{aligned}
& \mathrm{E}\left[\log [\mathrm{L}(\theta)] \mid \mathrm{y}_{\mathrm{h}}, \hat{\theta}^{(\mathrm{r}-1)}\right] \\
& =\sum_{\mathrm{k}=1}^{\mathrm{K}}\left[\sum_{\mathrm{h}=1}^{\mathrm{n}}\left[\log \tau_{\mathrm{k}}^{(\mathrm{r})}-\frac{\mathrm{p}}{2} \log 2 \pi-\sum_{\mathrm{i}=1}^{\mathrm{p}} \log {\sigma_{\mathrm{ik}}^{2}}^{(\mathrm{r})}-\frac{1}{2} \sum_{\mathrm{i}=1}^{\mathrm{p}} \frac{\left(\mathrm{y}_{\mathrm{hi}} \mathrm{\mu}_{\mathrm{ik}}{ }^{(\mathrm{r})}\right)^{2}}{\sigma_{\mathrm{ik}}^{2}}\right]\right] . \\
& \mathrm{P}\left(\mathrm{k} \mid \mathrm{y}_{\mathrm{h}}, \hat{\tau}_{\mathrm{k}}{ }^{(\mathrm{r}-1)}, \hat{\mu}_{\mathrm{ik}}{ }^{(\mathrm{r}-1)}, \hat{\sigma}_{i k}^{2}{ }^{(\mathrm{r}-1)}\right)
\end{aligned}
$$

dengan:

$\mathrm{r} \quad=$ indeks iterasi

$\theta^{(\mathrm{r})}=$ himpunan nilai parameter pada iterasi ke-r

$\hat{\theta}^{(\mathrm{r}-1)}=$ himpunan nilai parameter pada iterasi ke-(r-1)

ii. Tahap $\mathbf{M}$ bertujuan untuk menghitung nilai taksiran parameter atau estimator untuk memaksimumkan fungsi log likehood menggunakan nilai yang telah didapat pada tahap E. Berdasarkan persamaan (2.8), akan dicari nilai taksiran dari $\tau_{k}{ }^{(r)}, \mu_{\mathrm{ik}}{ }^{(\mathrm{r})}, \sigma_{\mathrm{ik}}^{2(\mathrm{r})}$ dengan menurunkan secara parsial terhadap masing-masing parameter.

$$
\begin{aligned}
& \hat{\tau}_{\mathrm{k}}{ }^{(\mathrm{r})}=\sum_{\mathrm{h}=1}^{\mathrm{n}} \frac{\mathrm{P}\left(\mathrm{k} \mid \mathrm{y}_{\mathrm{h}}, \hat{\mathrm{t}}_{\mathrm{k}}{ }^{(\mathrm{r}-1)}, \hat{\mu}_{\mathrm{ik}}{ }^{(\mathrm{r}-1)}, \hat{\sigma}_{i k}^{2}{ }^{(\mathrm{r}-1)}\right)}{n} \\
& \hat{\mu}_{i k}{ }^{(r)}=\frac{\sum_{\mathrm{h}=1}^{\mathrm{n}} \mathrm{y}_{\mathrm{hi}} P\left(\mathrm{k} \mid \mathrm{y}_{\mathrm{h}}, \hat{\tau}_{\mathrm{k}}{ }^{(\mathrm{r}-1)}, \hat{\mu}_{\mathrm{ik}}{ }^{(\mathrm{r}-1)}, \hat{\sigma}_{i k}^{2}{ }^{(\mathrm{r}-1)}\right)}{n \tau_{k}{ }^{(r)}} \\
& \hat{\sigma}_{i k}^{2}{ }^{(\mathrm{r})}=\frac{\sum_{h=1}^{n} \sum_{k=1}^{K}\left(\mathrm{y}_{\mathrm{hi}}-\mu_{\mathrm{ik}}{ }^{(\mathrm{r})}\right)^{2} \mathrm{P}\left(\mathrm{k} \mid \mathrm{y}_{\mathrm{h}}, \hat{\tau}_{\mathrm{k}}{ }^{(\mathrm{r}-1)}, \hat{\mu}_{\mathrm{ik}}{ }^{(\mathrm{r}-1)}, \hat{\sigma}_{i k}^{2}{ }^{(\mathrm{r}-1)}\right)}{\sum_{\mathrm{h}=1}^{\mathrm{n}} \mathrm{P}\left(\mathrm{k} \mid \mathrm{y}_{\mathrm{h}}, \hat{\tau}_{\mathrm{k}}{ }^{(\mathrm{r}-1)}, \hat{\mu}_{\mathrm{ik}}{ }^{(\mathrm{r}-1)}, \hat{\sigma}_{i k}^{2}{ }^{(\mathrm{r}-1)}\right)}
\end{aligned}
$$

Langkah selanjutnya yaitu menghitung nilai peluang posterior $\hat{P}\left(k \mid y_{h}, \hat{\theta}^{(r)}\right)$ yang baru berdasarkan nilai taksiran parameter yangdiperoleh pada tahap $\mathrm{M}$ sebelumnya, sehingga dapat dituliskan pada persamaan berikut:

$$
\hat{\mathrm{P}}\left(\mathrm{k} \mid \mathrm{y}_{\mathrm{h}}, \hat{\tau}_{\mathrm{k}}{ }^{(\mathrm{r})}, \hat{\mu}_{\mathrm{ik}}{ }^{(\mathrm{r})}, \hat{\sigma}_{i k}^{2}{ }^{(\mathrm{r})}\right)=\frac{\hat{\tau}_{\mathrm{k}}{ }^{(\mathrm{r})} \mathrm{g}\left(\mathrm{y}_{\mathrm{h}} \mid \hat{\mu}_{\mathrm{ik}}{ }^{(\mathrm{r})}, \hat{\sigma}_{i k}^{2}{ }^{(\mathrm{r})}\right)}{\sum_{\mathrm{k}=1}^{\mathrm{K}} \hat{\tau}_{\mathrm{k}}{ }^{(\mathrm{r})} \mathrm{g}\left(\mathrm{y}_{\mathrm{h}} \mid \hat{\mu}_{\mathrm{ik}}{ }^{(\mathrm{r})}, \hat{\sigma}_{i k}^{2}{ }^{(\mathrm{r})}\right)}
$$

Proses tahap $\mathrm{E}$ dan tahap $\mathrm{M}$ dilakukan secara berulang dengan menggunakan nilai taksiran pada persamaan (5), (6), (7), dan (9) hingga mencapai nilai dugaan parameter yang konvergen. Setelah tahap E dan tahap M selesai dilakukan dan diperoleh nilai taksiran parameternya, selanjutnya digunakan metode NR untuk memaksimumkan nilai taksiran parameter tersebut.

NR merupakan metode iterasi yang dimulai dengan nilai awal dari parameter $\theta^{(0)}$. Dalam setiap iterasi, dihitung vektor gradien yang merupakan turunan pertama dari fungsi log-likehood yang dinotasikan oleh $\mathrm{g}(\theta)$ dan matriks Hessian yang merupakan turunan kedua yang dinotasikan oleh $\mathrm{H}$. Hasil dari parameter dalam iterasi $(\mathrm{r}+1)$ 
dihitung menggunakan vektor gradien dan invers dari matriks Hessian yang berasal dari iterasi $\mathrm{r}$ (Snellman, 2008). Nilai taksiran parameter $\left(\hat{\theta}^{(0)}\right)$ yang didapatkan dapat digunakan untuk memaksimumkan nilai fungsi log-likelihood.

Selanjutnya dilakukan pemilihan model untuk mengetahui model terbaik. Kriteria pemilihan model pada LCCA dengan variabel indikator kontinu dilakukan menggunakan sifat parsimony (Vermunt dan Magidson, 2002b). Parsimony adalah sifat yang menghubungkan antara kecocokan model dengan banyaknya parameter dalam model yang bersangkutan. Pemilihan model terbaik dilakukan berdasarkan nilai terkecil Bayesian Information Criterion (BIC). Secara umum formulasi yang digunakan adalah:

dengan

$$
\mathrm{BIC}=-2[\log (\mathrm{L}(\hat{\theta}))]+\ln (\mathrm{N}) \mathrm{M}
$$

$$
\begin{array}{ll}
\log (\mathrm{L}(\hat{\theta})) & =\text { fungsi loglikelihood yang sudah dimaksimumkan untuk } \\
\mathrm{M} & \text { model dan data } \\
\mathrm{N} & =\text { jumlah parameter bebas yang di duga dalam model } \\
& =\text { jumlah data observasi }
\end{array}
$$

Setelah diperoleh model terbaik maka langkah selanjutnya yaitu mengelompokkan objek ke dalam cluster yang dilakukan dengan menghitung peluang posterior dari masing-masing objek terhadap cluster yang terbentuk. Peluang suatu objek masuk pada suatu cluster dinyatakan sebagai berikut:

$$
\mathrm{P}\left(\mathrm{K} \mid \mathrm{y}_{\mathrm{h}}, \hat{\theta}\right)=\frac{\hat{\tau}_{\mathrm{k}} \mathrm{g}\left(\mathrm{y}_{\mathrm{h}} \mid \hat{\theta}\right)}{\sum_{\mathrm{k}=1}^{\mathrm{K}} \hat{\tau}_{\mathrm{k}} \mathrm{g}\left(\mathrm{y}_{\mathrm{h}} \mid \hat{\theta}\right)}
$$

Pemilihan anggota dari suatu cluster dilakukan dengan melihat nilai peluang posterior tertinggi dari suatu objek di setiap clusternya (Vermunt dan Magidson, 2002b).

Pada model LCCA setiap variabel yang berada dalam satu cluster harus saling bebas atau kebebasan lokal antara variabel dengan tipe yang sama dalam satu cluster (Vermunt dan Magidson, 2004). Pelanggaran asumsi ini dapat dideteksi menggunakan statistik uji Bivariate Residual (BVR) dengan persamaan berikut:

$$
\mathrm{BVR}=\frac{\sum_{\mathrm{i}=1}^{\mathrm{I}} \sum_{\mathrm{j}=1}^{\mathrm{J}} \frac{\left(\mathrm{O}_{\mathrm{ij}}-\mathrm{E}_{\mathrm{ij}}\right)^{2}}{\mathrm{E}_{\mathrm{ij}}}}{\mathrm{db}}
$$

dengan

$$
\begin{array}{ll}
\mathrm{O}_{\mathrm{ij}} & =\text { frekuensi observasi } \\
\mathrm{E}_{\mathrm{ij}} & =\text { frekuensi harapan } \\
\mathrm{db}=(\mathrm{I}-1)(\mathrm{J}-1) & =\mathrm{I} \text { merupakan banyak baris dan } \mathrm{J} \text { banyak kolom dari tabel } \\
& \text { kontingensi } 2 \times 2 .
\end{array}
$$

Pada taraf signifikansi 5\% hipotesis nol ditolak ketika $B V R>3,84$. Apabila asumsi tidak terpenuhi dapat diatasi dengan cara menghilangkan salah satu variabel, menambah variabel atau juga dapat dilakukan dengan melakukan direct effect (penggabungan variabel).

\section{HASIL DAN PEMBAHASAN}

Tahap pertama adalah pengujian normalitas yang dilakukan pada semua variabel. Pengujian normalitas dilakukan menggunakan Uji Saphiro Wilk dengan nilai $\alpha=0,05$. Hasil pengujian dapat dilihat pada Tabel 2 . 
Tabel 2 Hasil Uji Normalitas

\begin{tabular}{lrrl}
\hline \multicolumn{1}{c}{ Variabel } & $\mathrm{W}_{\text {hit }}$ & p-value & Kesimpulan \\
\hline Kepadatan Penduduk & 0,39 & 0,00 & Tidak Normal \\
Rasio Ketergantungan & 0,99 & 1,00 & Normal \\
UHH & 0,91 & 0,19 & Normal \\
Morbiditas & 0,96 & 0,71 & Normal \\
Lengkap Imunisasi & 0,93 & 0,37 & Normal \\
RLS & 0,93 & 0,32 & Normal \\
HLS & 0,94 & 0,48 & Normal \\
TPT & 0,84 & 0,03 & Tidak Normal \\
TPAK & 0,89 & 0,08 & Normal \\
Pengeluaran Per Kapita Per Bulan & 0,88 & 0,07 & Normal \\
Rasio Gini & 0,94 & 0,42 & Normal \\
Akses PLN & 0,93 & 0,32 & Normal \\
Air Layak & 0,92 & 0,27 & Normal \\
Sanitasi & 0,69 & 0,00 & Tidak Normal \\
BBM Memasak & 0,92 & 0,26 & Normal \\
\hline
\end{tabular}

Hasil pengujian pada Tabel 2 menunjukan bahwa terdapat tiga variabel yaitu kepadatan penduduk, TPT dan sanitasi memiliki nilai $\mathrm{p}$-value $<\alpha$ sehingga $\mathrm{H}_{0}$ ditolak. Penolakan $\mathrm{H}_{0}$ berarti galat tidak berdistribusi normal, sehingga diperlukan transformasi untuk permasalahan tersebut. Transformasi dilakukan menggunakan metode Box-Cox yang hasilnya dapat dilihat pada tabel 3 .

Tabel 3 Hasil Uji Tranformasi Box-Cox

\begin{tabular}{lcccc}
\hline \multicolumn{1}{c}{ Variabel } & Nilai " $\lambda$ " & $\mathrm{W}_{\text {hit }}$ & p-value & Kesimpulan \\
\hline Kepadatan Penduduk & $-0,5$ & 0,917 & 0,227 & Normal \\
TPT & 0 & 0,955 & 0,670 & Normal \\
Sanitasi & 5 & 0,880 & 0,071 & Normal \\
\hline
\end{tabular}

Setelah data memenuhi asumsi kenormalan selanjutnya yaitu pendugaan parameter setiap model menggunakan Algoritma EM dan Metode NR. Hasil iterasi kedua metode tersebut sebagai berikut

$\begin{array}{cccc}\begin{array}{c}\text { Iteration } \\ \text { Detail } \\ \text { Starting Set }\end{array} & \begin{array}{c}\text { Log } \\ \text { Posterior }\end{array} & \begin{array}{c}\text { Log } \\ \text { Likelihood }\end{array} & \text { Seed } \\ 1 & -898,10307 & -830,994074 & 156902 \\ 2 & -895,76846 & -832,005277 & 344167 \\ 3 & -881,03062 & -814,47598 & 2139383\end{array}$




$\begin{array}{ccccc} & 4 & -959,39822 & -901,385688 & 1709420 \\ 5 & -898,64984 & -834,442196 & 1082558 \\ 6 & -873,66928 & -804,867578 & 651405 \\ 7 & -914,91979 & -850,85691 & 1925918 \\ 8 & -902,8086 & -840,290701 & 1234569 \\ & 9 & -868,52036 & -800,482639 & 298613 \\ & 10 & -894,59762 & -829,462875 & 1824774 \\ & 11 & -931,71382 & -871,460258 & 2142426 \\ & 12 & -907,38692 & -844,345024 & 1041637 \\ & 13 & -935,84486 & -874,929489 & 2029694 \\ & 14 & -930,63184 & -867,223196 & 2626723 \\ & 15 & -918,02423 & -854,594252 & 2371654 \\ & 16 & -888,48396 & -822,688813 & 1085080 \\ & 1 & -888,48396 & -800,482639 & 298613 \\ & 2 & -873,66928 & -804,867578 & 651405 \\ \text { EM } & \text { Iteration } & \text { log- } & \text { log- } & \text { criterion } \\ & & \text { posterior } & \text { likelihood } & \\ & 0 & -868,52036 & -800,482639 & \\ & 2 & -868,52036 & -800,482639 & 4,15 \mathrm{E}-06 \\ & 1 & -868,52036 & -800,482639 & 1,864 \mathrm{E}- \\ & & & & 05 \\ & 2 & -868,52036 & -800,482639 & 0,000000 \\ & & & & \end{array}$

Selanjutnya dilakukan pemilihan model yaitu dengan membandingkan nilai BIC pada setiap model yang dihasilkan.

Tabel 4 Nilai BIC, Maksimum Loglikelihood dan Npar Bebas Setiap Model

\begin{tabular}{lrcc} 
Model & Maksimum LL & BIC(LL) & Npar Bebas \\
\hline Model 1 & $-842,0131$ & 1840,4881 & 61 \\
Model 2 & $\mathbf{- 8 0 0 , 4 8 2 6}$ & $\mathbf{1 8 3 6 , 9 4 0 6}$ & $\mathbf{9 2}$ \\
Model 3 & $-788,8087$ & 1893,1063 & 123 \\
Model 4 & $-747,5673$ & 1890,1368 & 154 \\
Model 5 & $-730,2242$ & 1934,964 & 185 \\
Model 6 & $-698,8218$ & 1951,6727 & 216 \\
Model 7 & $-681,0935$ & 1995,7295 & 247 \\
Model 8 & $-645,9751$ & 2005,0062 & 278 \\
Model 9 & $-677,9492$ & 2068,9544 & 278 \\
Model 10 & $-647,7602$ & 2088,0897 & 309 \\
Model 11 & $-626,7144$ & 2125,5116 & 340 \\
\hline
\end{tabular}

Berdasarkan Tabel 4 dapat diketahui bahwa nilai BIC terkecil ditemukan pada model kedua dengan 3 cluster, sehingga model ini merupakan model terbaik. Salah satu syarat 
yang harus dipenuhi untuk menyatakan bahwa model terbaik yang dihasilkan sudah cukup akurat adalah terpenuhinya asumsi kebebasan lokal, yaitu dengan melihat nilai BVR. Hasil pengujian menunjukan selang nilai BVR pada model 2 adalah 0,0325 2,528 dan tidak terdapat nilai BVR yang cukup besar $(>3,84)$ yang berarti bahwa asumsi kebebasan lokal terpenuhi. Setelah semua asumsi pada model terbaik terpenuhi, selanjutnya yaitu dilakukan pengelompokan objek yaitu kabupaten/kota ke dalam sebuah cluster berdasarkan peluang posterior terbesar dari setiap variabel. Peluang objek pada setiap cluster dapat dilihat tabel berikut.

\begin{tabular}{llccc}
\multicolumn{6}{l}{ Tabel } & Peluang Objek pada setiap Cluster \\
\hline No. & Nama Kabupaten & Cluster 1 & Cluster 2 & Cluster 3 \\
\hline 1 & Fakfak & 0,0004 & 0,9996 & 0,0000 \\
2 & Kaimana & 0,0735 & 0,9265 & 0,0000 \\
3 & Teluk Wondama & 0,0408 & 0,1286 & 0,0000 \\
4 & Teluk Bintuni & 0,0077 & 0,0000 & 0,9923 \\
5 & Manokwari & 0,0353 & 0,0000 & 0,0000 \\
6 & Sorong Selatan & 4,1506 & 0,0000 & 0,0000 \\
7 & Sorong & 0,0343 & 0,0001 & 0,0000 \\
8 & Raja Ampat & 4,5827 & 0,0827 & 0,0000 \\
9 & Tambarauw & 0,0001 & 0,0000 & 0,0000 \\
10 & Maybrat & 0,00017 & 0,00189 & 0,00000 \\
11 & Manokwari Selatan & 4,68137 & 0,00000 & 0,00000 \\
12 & Pegunungan Arfak & 0,00002 & 0,00000 & 0,00000 \\
13 & Kota Sorong & 0,00000 & 0,00000 & 0,63953 \\
\hline
\end{tabular}

Hasil pengelompokan objek pada setiap cluster disajikan pada gambar 1 berikut: Gambar 1 Pemetaan Indikator Kesejahteraan Rakyat Papua Barat

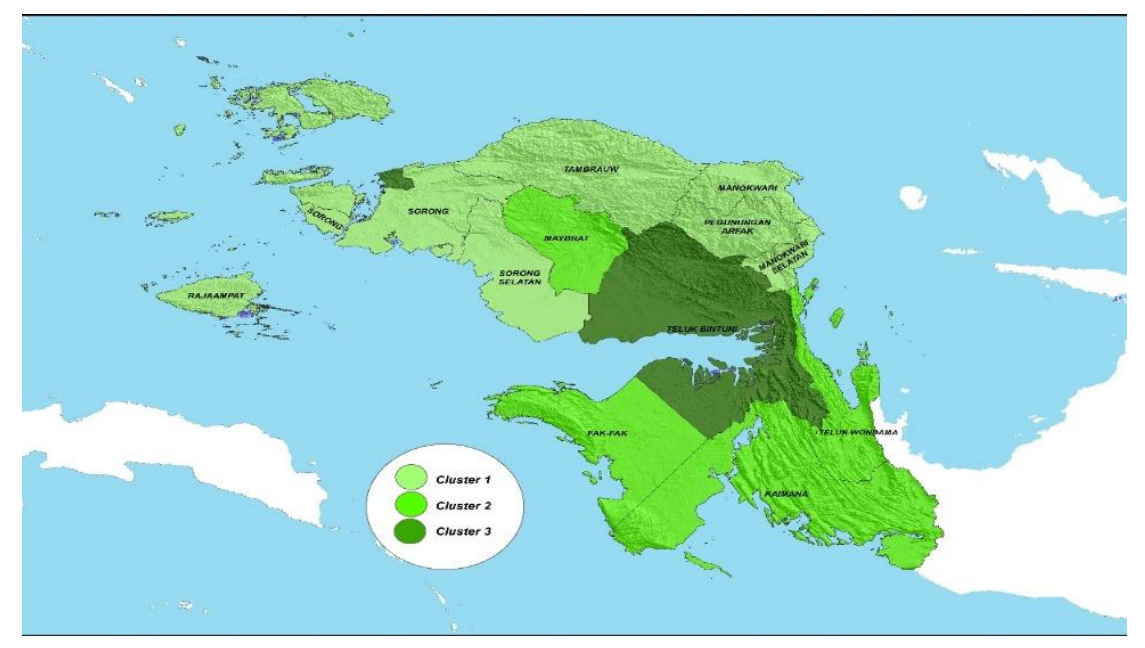

Cluster 1 terdiri dari Kabupaten Manokwari, Kabupaten Sorong Selatan, Kabupaten Sorong, Kabupaten Raja Ampat, Kabupaten Tambrauw, Kabupaten Manokwari Selatan, dan Kabupaten Pegunungan Arfak. Cluster 2 terdiri dari Kabupaten Fakfak, Kabupaten Kaimana, Kabupaten Maybrat dan Kabupaten Teluk Wondama. 
Cluster 3 terdiri dari Kabupaten Bintuni dan Kota Sorong. Sedangkan karakteristik yang terbentuk dari masing-masing cluster dapat dilihat pada Tabel 6.

Tabel 6 Rata-rata Variabel pada Setiap Cluster yang Terbentuk

\begin{tabular}{lccc}
\hline \multirow{2}{*}{ Variabel } & \multicolumn{3}{c}{ Rata-Rata } \\
\cline { 2 - 4 } & Cluster 1 & Cluster 2 & Cluster 3 \\
\hline Kepadatan Penduduk $\left(\mathrm{X}_{1}\right)$ & 14,35 & 6,09 & 189,66 \\
Rasio Ketergantungan $\left(\mathrm{X}_{2}\right)$ & 56,70 & 52,53 & 49,04 \\
UHH $\left(\mathrm{X}_{3}\right)$ & 65,40 & 64,21 & 65,08 \\
Morbiditas $\left(\mathrm{X}_{4}\right)$ & 10,96 & 12,71 & 11,31 \\
Balita Lengkap Imunisasi $\left(\mathrm{X}_{5}\right)$ & 29,47 & 41,12 & 50,15 \\
TPAK $\left(\mathrm{X}_{6}\right)$ & 73,64 & 65,23 & 70,05 \\
TPT $\left(\mathrm{X}_{7}\right)$ & 3,62 & 4,46 & 8,57 \\
RLS $\left(\mathrm{X}_{8}\right)$ & 6,72 & 7,47 & 9,35 \\
HLS $\left(\mathrm{X}_{9}\right)$ & 12,31 & 12,33 & 13,08 \\
Pengeluaran per Kapita per Bulan & & & \\
(X 10 & 938640,71 & 1157642,00 & 1386580,00 \\
Rasio Gini $\left(\mathrm{X}_{11}\right)$ & 0,36 & 0,40 & 0,34 \\
Akses PLN $\left(\mathrm{X}_{12}\right)$ & 63,51 & 67,58 & 85,50 \\
Air Layak Minum $\left(\mathrm{X}_{13}\right)$ & 31,50 & 46,07 & 34,55 \\
Sanitasi $\left(\mathrm{X}_{14}\right)$ & 87,92 & 94,71 & 97,40 \\
Bahan Bakar Memasak $\left(\mathrm{X}_{15}\right)$ & 51,14 & 58,85 & 79,02 \\
\hline
\end{tabular}

\section{KESIMPULAN}

Kesimpulan yang diperoleh adalah sebagai berikut:

1. Pengelompokan dilakukan dengan membuat beberapa model yang dimulai dari model 1 hingga model 11. Berdasarkan kriteria BIC diperoleh model terbaik adalah model 2 dengan 3 cluster dan telah memenuhi asumsi kenormalan dan kebebasan lokal.

2. Anggota cluster 1 terdiri dari Kabupaten Manokwari, Kabupaten Sorong Selatan, Kabupaten Sorong, Kabupaten Raja Ampat, Kabupaten Tambrauw, Kabupaten Manokwari Selatan, dan Kabupaten Pegunungan Arfak. Indikator morbiditas, balita lengkap imunisasi, RLS, TPT, pengeluaran per kapita per bulan, akses PLN, air layak minum, sanitasi dan bahan bakar memasak memiliki rata-rata terendah sedangkan indikator rasio ketergantungan, UHH dan TPAK memiliki rata-rata tertinggi pada cluster ini.

3. Anggota cluster 2 terdiri dari dari Kabupaten Fakfak, Kabupaten Kaimana, Kabupaten Maybrat dan Kabupaten Teluk Wondama. Indikator kepadatan penduduk, UHH, dan TPAK memiliki ratarata terendah sedangkan indikator morbiditas, air layak minum dan sanitasi memiliki rata-rata tertinggi pada cluster ini.

4. Anggota cluster 3 terdiri dari dari Kabupaten Bintuni dan Kota Sorong. Indikator kepadatan penduduk, balita lengkap imunisasi, RLS, HLS, TPAK, Pengeluaran per kapita per bulan, akses PLN, sanitasi dan bahan bakar memasak memiliki rata- 
rata tertinggi sedangkan indikator air layak minum memiliki rata-rata

\section{DAFTAR PUSTAKA}

Anonim. 2013. Perda Papua Barat Nomor 18 Tahun 2012. http://www.jdih.setjen.kemendagri. go.id/files/P_PAPUA_BARAT_18 2012.docx [12 Juli 2019]

[BPS] Badan Pusat Statistik. 2019. Indikator Kesejahteraan Rakyat 2019. http:// bps.go.id/ [10 September 2020]

[BPS] Badan Pusat Statistik. 2019. Indikator Kesejahteraan Rakyat Provinsi Papua Barat Tahun 2018. http://papuabarat.bps.go.id/ $\quad[10$ September 2020]

Box,G.E.P and Cox, D.R. 1964. An Analysis of Transformation. Journal of the Royal Statistikal Society. Series B (Methodological), Vol. 26, No. 2. (1964), pp.211-252.

Chadidjah, Anna. 2016. Latent Class Clustering Analysis Dalam Pengelompokan Kelurahan di DKI Jakarta Berdasarkan Ketelantaran Lansia. Seminar Pendidikan Nasional Matematika 2016. ISSN 2528-4630

Linda, M. Colins \& Stephanie, T. Lanza. 2010. Latent Class And Latent Transition Analysis with Application in The Sosial, Behavioral, and Health Sciences. New Jersey: John Wiley \& Sons, Inc

Mattjik, A. Anshori \& Sumertajaya, I Made. 2011. Sidik Variabel Ganda dengan menggunakan SAS. Edisi Pertama. IPB Press terendah pada cluster ini.

Nugroho, Sigit.2008. Statistika Multivariat Terapan. Edisi 1. UNIB Press

Snellman, Marja. 2008. Case Definition Of Pneumococcal Pneumonia A Latent Class Analysis Approach. Helsinki: National Public Health Institute.

Vermunt, J. K., \& Magidson, J.. 2002a. Latent Class Cluster Analysis. MA: Statistikal Innovations Inc

Vermunt, Jeroen K. \& Magidson, J. 2002b. Latent Class Models For Clustering: A Comparison of $K$ Means Clustering. MA: Statistikal Innovations Inc.

Vermunt, Jeroen K. \& Magidson, J. 2004. Latent class models. In D. Kaplan (Ed.), The Sage handbook of quantitative methodology for the sosial sciences (pp. 175-198). Sage. 